Det indskrænkede monarki og teorien om statsmagtens ligevægt

Møller, Jes Fabricius

Published in:

Historisk Tidsskrift

Publication date:

2014

Document version

Også kaldet Forlagets PDF

Citation for published version (APA):

Møller, J. F. (2014). Det indskrænkede monarki og teorien om statsmagtens ligevægt. Historisk Tidsskrift, 93(4), 539-564. http://www.idunn.no 


\section{Det indskrænkede monarki og teorien om statsmagtens ligevægt}

\section{Av Jes Fabricius Møller}

grundlov, der blev vedtaget $i$ juni 1849 , i lyset af en senere udvikling af parlamentarisme og moderne demokratiske idealer. Denne artikel søger at gøre op med denne whig interpretation ved hjolp af sammenligning med Eidsvollforfatningen og eksempler fra den politiske debat $i$ årtierne op til grundlovens vedtagelse og ved hjoelp af en loesning af grundlovens for størstedelen endnu bevarede ordlyd at argumentere for, at junigrundloven var toenkt som en slags blandet forfatning, monarchia mixta, hvis ideal er en ligevogt mellem statsmagtens dele.

jesfab@hum.ku.dk

Jes Fabricius Møller er professor (MSO) ved Aarhus Universitet og lektor ved Københavns Universitet.

Historisk tidsskrift

Bind 93, s. 539-564

(C) Universitetsforlaget 2014

\section{English} abstract p 678 


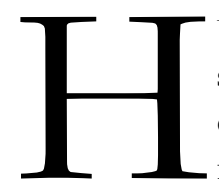

VILKEN STYREFORM blev indført i Danmark i $1849 ?^{1}$ Dette spørgsmål lader sig naturligvis i princippet besvare meget enkelt ved at konsultere grundloven. Ordene «Regeringsformen er indskrænket-monarkisk» har stået uforandret når bort ses fra skiftende ortografi - siden $1849 .{ }^{2}$ Spørgsmålet er naturligvis, hvad man skal lægge i dette udtryk?

Ikke mange af dem, der har beskæftiget sig med dansk, politisk historie eller forfatningshistorie, har imidlertid hæftet sig synderligt ved formuleringen som central for forståelsen af statsomvæltningen 1848$1849 \cdot{ }^{3}$ Den selv samme af Kongeloven regulerede enevælde var imidlertid som bekendt allerede afskaffet en gang før, nemlig i Norge i 1814, og det er interessant at iagttage, at den norske grundlovs første paragraf anvender præcis samme betegnelse for den valgte regeringsform: «Kongeriget Norge er et frit, uafhængigt og udeleligt Rige. Dets Regjeringsform er indskrænket og arvelig monarkisk.» ${ }^{4}$ Der kan da heller ikke herske nogen tvivl om, at Eidsvollforfatningens formulering danner forbillede for junigrundlovens.

En grundlov har kun en funktion og en rolle at spille for så vidt den bliver genstand for en udlægning, teoretisk såvel som praktisk, og denne udlægning er dynamisk, situationsafhængig og har som regel en klar politisk indebyrd og affinitet.

Eirik Holmøyvik har vist, hvordan tolkningen af den norske grundlov skiftede gennem det 19. århundrede. Forsamlingen på Eidsvoll byggede grundloven på folkesuverænitetsprincippet og forstod grundloven som et middel til at delegere den på dette fundament stående magt. Men få år senere var det en dominerende tolkning af Eidsvollforfatningen, at den var at forstå som et kontraktligt forhold mellem folket og kongen. I sammenhængen handlede det om proceduren for grundlovsændringer. Ifølge folkesuverænitetsprincippet kunne kun folkets repræsentanter ændre grundloven, mens den kontraktlige fortolkning indebar, at kongen ville have vetoret over for ændringsforslag. Denne forskydning i fortolkningen

1. Det følgende er en bearbejdning af et foredrag holdt i Det Kgl. Danske Selskab for Fædrelandets Historie 20. nov. 2013, gentaget i let ændret form i Kulturhistorisk Selskab 3. dec. 2013. Det bygger på min bog, Dynastiet Glücksborg - en danmarkshistorie, Kbh. 2013. Jeg skylder bl.a. Ola Mestad, Mogens Herman Hansen, Sebastian Olden-Jørgensen, Jens WendelHansen og Rasmus Glenthøj tak for frugtbare drøftelser og Historisk tidsskrifts to anonyme fagfællebedømmere en stor tak for omhyggelig og velanbragt kritik af artiklens første udkast.

2. Indtil 1953 i $\$$ 1, nu i $\$$ 2. Anvendt udgave er H. Koch og K. Hvidt, Danmarks Riges Grundlove, Kbh. 1999 .

3. D. Tamm, $\S_{2}$, i H. Zahle (red.), Danmarks Riges Grundlov med kommentarer, Kbh. 2006: 124 .

4. Forfatningerne kan findes i faksimile på http://www.modern-constitutions.de. 
- mest karakteristisk repræsenteret ved penneføreren på Eidsvoll, Falsens holdningsændring - sætter Holmøyvik i forbindelse med den europæiske restauration efter 1815 . Først med forfatningskampen i 188 oerne vendte man tilbage til den oprindelige tanke. ${ }^{5}$

Det er påstanden i denne artikel, at fortolkningen af den danske grundlov af 1849 i store træk har foretaget den modsatte bevægelse af den norske, en forskydning fra den indledende forståelse, at kongen spillede en central rolle, til den opfattelse, at Rigsdagen og især Rigsdagens Folketing stod i centrum, men forskudt i tid, således at den foregik parallelt med den norske i det 19. århundredes sidste halvdel.

I Danmark har opmærksomheden ikke i samme grad været rettet mod dynamikken eller foranderligheden i grundlovsfortolkningerne. Eller man kan vel rettere sige, at det er den dominerende opfattelse, at junigrundloven fra begyndelsen stod fast på folkesuverænitetsprincippet. Det er udtrykt senest af professor i økonomi Ove Kaj Pedersen: «Med Grundloven 1849 overdrages den koncentrerede suverænitet til Rigsdagen.» 6

Denne tolkning hænger sammen med, at de fleste, der beskæftiger sig med grundloven - den norske såvel som den danske - ser den i en demokratihistorisk sammenhæng og ikke i en monarkihistorisk. Det er i sig selv en fuldstændig legitim tilgang til stoffet, men som alle forskningsstrategier belyser den noget og lægger andet i skyggen.

En demokratihistorisk vinkel på statsomvæltningen 1848-49 lægger vægt på grundlovens demokratiske elementer henholdsvis demokratiske mangler. Valgrets- og valgbarhedsbestemmelserne til Rigsdagen behandles altid udførligt i historikernes behandling af grundloven. Fordi forholdet mellem Rigsdagen og ministeriet fik en så stor betydning for den politiske udvikling senere hen, har det også nydt stor opmærksomhed blandt historikere. Kongens rolle derimod - både i processen op til og under den nye forfatning - nedtones betragteligt.

Tolkningen er selvfølgelig ikke helt uden hjemmel. Den nytiltrådte konge, Frederik VII, havde valgt ved et møde i Statsrådet den 22. marts ${ }_{184} 8$ at betegne sig selv om konstitutionel monark. ${ }^{7}$ Det er ofte den handling, der henvises til, når der kræves belæg for det forhold, at junigrundloven indførte konstitutionelt monarki, mens det er ganske almin-

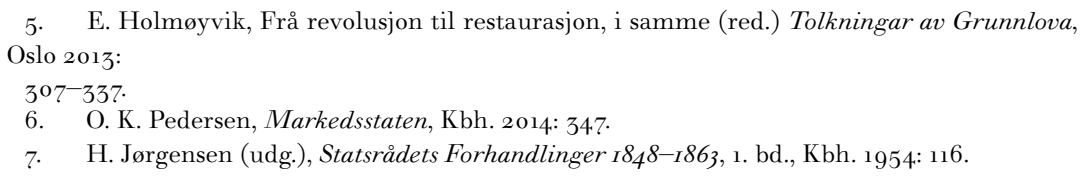


deligt at ignorere grundlovens egen ordlyd: «Grundloven fastslog, at regeringsformen var et konstitutionelt monarki», skrev Claus Bjørn f.eks. i sit bind til Gyldendal og Politikens danmarkshistorie. ${ }^{8}$ Selv i Folketingets officielle oversættelse af grundloven til engelsk hedder det næsten som en besværgelse: «The form of government shall be that of a constitutional monarchy.» 9

33 af junigrundlovens 100 paragraffer omhandler kongens rolle. Tim Knudsen har i sit autoritative værk om dansk demokratihistorie klart identificeret dette forhold, men forklarer det med, at kongens fremtrædende rolle i den skrevne forfatning var en formalitet, et hensyn til et almindeligt ønske om at foregive kontinuitet, der kun havde ringe berøring med den politiske virkelighed: «Sammenkoblingen af det gamle kongestyre og den ny tids regering og Rigsdag blev indhyllet i tåget symbolsprog.» ${ }^{10}$

Grundlovens demokratiske element er vigtigt. Det kan ikke benægtes, at begivenhederne $1848-49$ indtager en central stilling i historien om det danske demokrati, men det er lige så klart, at der er en dominerende tendens til at reducere junigrundloven til et overgangsfænomen mellem enevælde og demokrati. ${ }^{11}$ Hvad der måtte være af demokratiske elementer, forstås som forstadier til et moderne demokrati, og hvad der identificeres som demokratiske mangler, afskrives som en uhensigtsmæssig arv af enevælde, og processen beskrives gennemgående under anvendelse af begreber som «tilbageslag» og «fremskridt», «progression» og «reaktion». Denne tilgang er typisk for «The whig historian», der fra sit ståsted i det 20. århundrede ser tilbage på det 19. og kun ser begyndelser på, som det siden blev til. ${ }^{12}$

Denne whig interpretation fik sit klareste udtryk i Claus Friisbergs disputats om parlamentarismens historie, hvori Friisberg hævdede som en af hovedteserne, at parlamentarismen lå «på bunden af Junigrundloven». ${ }^{13}$ Det gjorde den kun for så vidt parlamentarismen voksede ud af junigrundloven og dens senere revisioner, men det lader sig relativt let påvise, at det bestemt ikke var intentionen med grundloven at lade Rigsdagen få kontrol med regeringsdannelsen. ${ }^{14}$

\footnotetext{
8. C. Bjørn, Fra reaktion til grundlov, Kbh. 1990: 345 .

9. The Constitutional Act of Denmark of June 5, 1953, udg. af Folketinget, Kbh. 1999.

10. T. Knudsen, Fra enevalde til folkestyre, Kbh. 20o6: 118.

11. Således meget klart i N. F. Christiansens forskningsoversigt, Grundloven, historikerne og det moderne Danmark, Den jyske Historiker nr. 83/84, 1999: 7-32.

12. H. Butterfield, The Whig Interpretation of History, 1931, kap. 2.

13. C. Friisberg, Ingen over og ingen ved siden af Folketinget. Partiernes kamp om forfatningen $1848-1920$, I-II, Varde 2007.

14. Se diskussion i (dansk) Historisk Tidsskrift, 108, hft. 1 og 2.
} 
I sin bog om demokratiets begrebshistorie gør Jeppe Nevers opmærksom på, at demokratiet ikke blev indført i 1849 ; ikke fordi forfatningen havde demokratiske mangler, hvad den unægtelig havde, men simpelthen fordi demokratiet som styreform ikke var på tale i andet end negativ forstand. Demokrati var nærmest et skældsord. Man knyttede som hovedregel forestillinger om pøbelvælde eller anarki til det rene demokrati som styreform. ${ }^{15}$

Bertel Nygaard har i en studie modificeret Nevers' tese ved at vise, at netop i 1848 blev demokrati brugt i en positiv betydning af en kreds af aktører omkring Kjøbenhavnsposten og Hippodrombevægelsen. ${ }^{16}$ Det er også muligt at finde eksempler på, at demokratiet er blevet brugt i en positiv betydning før den tid, men hovedindtrykket er stadig skepsis over for demokratiet som styreform. Jeg vil i det følgende gøre gældende, at Nevers har ret for så vidt angår det rene demokrati, men at det i samtiden var almindeligt og acceptabelt at tale om, at der i et konstitutionelt styre indgik et demokratisk element.

Den politiske kamp i 1848-49 stod heller ikke mellem monarki og republik. At ingen eller meget få havde forestillet sig en republik er en så indlysende omstændighed, at den ofte glemmes. Det skyldtes ikke blot det for Danmark helt konkrete forhold, at Helstaten - et begreb der kom i brug i det 19. århundredes statsretlige diskussioner - var en dynastisk union, der næppe lod sig opretholde som republik, men at staten som princip dårligt kunne tænkes uden et monarkisk overhoved. Monarkiet var en integreret og uomgængelig del af enhver konstitutionel debat såvel i 1814 , som i 1849 .

Næsten samtlige europæiske stater fik i perioden $1800^{-1} 85^{\circ}$ en forfatning, og et helt nyt Europa blev til. Denne omvæltning fandt sted i en periode, der gerne betegnes som «Restauration», men det ville være misvisende at kalde epoken for konservativ i den forstand, at der eksisterede en realistisk ambition om at restaurere l'ancien régime. Der var heller ikke tale om de europæiske monarkiers teminalfase, en midlertidig overgangsfase inden demokratiets og/eller republikkens endelige frembrud. ${ }^{17}$ Det Europa, der blev til efter Napoleon, blev ikke bygget op på trods af monarkerne, men i kraft af dem og ved hjælp af dem. Det borgerlige århundrede var med Dieter Langewiesches ord fyrstestaternes århundrede.

\footnotetext{
15. J. Nevers, Fra skaldsord til slagord-Demokratibegrebet i dansk politisk historie, Odense 2011.

16. B. Nygaard, Demokratibegrebets gennembrud i Danmark i 1848, (dansk) Historisk Tidsskrift $111 / 1$.

17. C. A. Bayly, The Birth of the Modern World 1780-19I4, Oxford 2004: 427.
} 
Dieses neue Europa, an dessen Beginn eine Gewalt steht, die legitime Herrschaft vernichtete und zugleich eine Ära der Revolution und des ständigen Krieges beendete, blieb - trotz Revolution, trotz Staatszerstörung und Staatserschaffung - ein Europa der Dynastien. Kein neuer Staat entstand damals ohne fürstliches Haupt. Das bürgerliche Säkulum wurde zu einem Jahrhundert der Fürstenstaaten. ${ }^{18}$

Det nye var ikke, at monarkiet som stats- eller styreform forblev normen, men at monarkierne næsten overalt blev kodificerede. Foregangsland var Frankrig, der således fortsatte med at udgøre udgangspunkt for de revolutionære omvæltninger. La Charte Constitutionelle fra 1814 dannede forbillede for den række af konstitutioner, som blev udbredt i Europa efter 1815. Hverken den spanske af 1812, dens svenske af 1809 eller Eidsvollforfatningen af 1814 , havde den samme indflydelse. ${ }^{19}$

Den franske forfatning blev givet efter en konflikt mellem senatet og den designerede tronfølger. Det var senatet, der formelt havde afsat Napoleon og nu ønskede at genindsætte bourbon'erne på tronen. Imidlertid lod den udsete tronkandidat, Louis-Stanislas Xavier, comte de Provence, sig ikke indsætte, men betragtede sig fra første færd som den lovlige konge, Ludvig XVIII, og han handlede ud fra den grundsætning, der blev kendt som det monarkiske princip, det vil sige at al statsmagt udgår fra kongen. ${ }^{20}$ Hvis Frankrig skulle have en forfatning, skulle den gives af ham, og det lykkedes ham at sætte sin vilje igennem over for senatet. Den 2. maj 1814 udstedte han løfte om at give Frankrig une constitution libérale. ${ }^{21}$

Det er sigende, at en forfatning både kan bygge på det monarkiske princip og samtidig kalde sig libérale. Her er der grund til at understrege, at det forhold, at det monarkisk princip overhovedet bliver lovfæstet i sig selv indebærer en indskrænkning af kongemagten. I den forstand var restaurationen en fortsættelse af de revolutionære principper, fordi den i al sin tilsyneladende konservatisme var helt indforstået med, at ingen magt eller magtudøvelse fremover var legitimerbar, med mindre den lod sig kodificere. Det ligger i forlængelse af den omfattende statsretlige diskussion i Europa i det 17. og ikke mindst 18. århundrede om kongemag-

18. D. Langewiesche, Die Monarchie im Europa des bürgerlichen Jahrhunderts. Das Königreich Württemberg, i Das Königreich Württemberg I806-I9I8. Monarchie und Moderne. Ausstellungskatalog, Stuttgart 2006: 26.

19. M. Prutsch, Making sense of constitutional monarchy in Post-Napoleonic France and Germany, New York 2012: 70. Se også M. Kirsch, Monarch und Parlament im 19. Jahrhundert, Göttingen 1999. Cf. Holmøyvik 2013.

20. Begrebet blev introduceret af Schlegel i det 19. århundredes første årti. Holmøyvik 2013: 312. Begrebet fik sin teoretiske udformning af Benjamin Constant og ikke mindst Friederich Julius Stahl, Das Monarchische Princip, Heidelberg 1845. Se også Prutsch 2012: 190.

21. Louis XVIII, Mon dernier mot, Paris 1814: 12. 
tens indskrænkning. Den kunne, som bl.a. Ola Mestad har vist, sagtens finde sted også i Europas formelt mest enevældige monarki, det danske. ${ }^{22}$ Hvis man tager udgangspunkt $\mathrm{i}$ et moderne begreb om magtfordeling, altså en funktionel magtdeling mellem lovgivende, udøvende og dømmende magt, kan man hævde, at «der ikke synes at være belæg for, at magtfordelingslæren skulle have spillet nogen rolle for dansk forfatningsret før grundloven af $1849 .{ }^{23}$ Men taget i en blot lidt videre forstand, altså som en forestilling om en indskrænkning af monarkens magt, fandt der en omfattende diskussion sted.

Indskrænket monarki (monarchia limitata) blev dannet som begreb i tidlig moderne tid hos tænkere som Grotius og Pufendorf parallelt med og som reaktion på det absolutte eller uindskrænkede monarki (monarchia absoluta). ${ }^{24}$ Det bygger på, hvad Horst Dreitzel kalder en «skranketeori», ${ }^{25}$ altså en forestilling om, at der for denne magts udøvelse burde opsættes skranker for at monarkiet ikke skulle udarte til despoti. Foruden den moralske skranke, hvormed kristendommen og/eller kirken bandt kongens handlinger, kan der i samtidens statsretsteori identificeres to hovedtyper: for det første en indskrænkning af suverænens magt i form af lovgivning og for det andet en indskrænkning i form af en inddragelse af andre end monarken selv i magtens udøvelse og forvaltning, i form af f.eks. en stænderforsamling, et senat eller anden form for repræsentation af dem, over hvem magten udøvedes.

Den sidstnævnte form for indskrænkning kunne også kaldet «monarchia mixta» eller «respublica mixta». ${ }^{26}$ Den teoretiske skelnen mellem det indskrænkede og det blandede monarki var, at i det indskrænkede forblev suveræniteten hos monarken, der af egen vilje lod sin magt indskrænke. Fortalerne for denne form for monarki, f.eks. Pufendorf, mente, at det var den eneste måde at sikre suveræniteten. Pufendorf kaldte den blandede forfatningsform for «respublica irregularis», en korrumperet statsform. ${ }^{27}$

Heroverfor stod fortalerne for den blandede forfatning, der nød stigende tilslutning blandt teoretikerne i det 18. århundrede. Den mest

22. O. Mestad (red.), Frihetens forskole. Professor Schlegel og eidsvollmennenes laretid $i$ København, Oslo 2013: passim.

23. H. P. Olsen, Magtfordeling. En analyse af magtfordelingslaeren med sarligt henblik på den lovgivende magt, Kbh. 2005: 175 , cf. s. 97 f.

24. Det følgende bygger på H. Dreitzel, Monarchiebegriffe in der Fürstengesellschaft, Wien 1991, bd. 1: $82 \mathrm{ff}$.

25. Dreitzel 1991: 106.

26. Fx i Pufendorf, De jure naturae et gentium, 1672, iflg. Dreitzel 1991: $9^{8}$.

27. Dreitzel 1991: 99 . 
berømte og indflydelsesrige fortaler for et magtdelingsprincip er naturligvis Montesquieu, men det trak igen på en langt ældre forfatningsteori, der går tilbage til antik græsk politisk tænkning, ikke mindst Aristoteles, der arbejdede med tre rene forfatningsformer, den monarkiske, den aristokratiske og den demokratiske eller politeia. Hver af disse rene styreformer havde positive egenskaber, men hvis de stod alene, risikerede de at udarte til tyranni, oligarki eller anarki, og derfor blev den blandede forfatning et ideal, fordi i den stat, der i sig rummede balancen mellem demokratiske, aristokratiske og monarkiske elementer, ville der herske stabilitet, harmoni og retfærdighed. Gennem historikeren Polybios fik denne teori om den blandede forfatning et langt efterliv, og den var naturligvis kendt - om end langt fra delt - af enhver klassisk dannet politisk tænker i det 18. og 19. århundrede. ${ }^{28}$

Det er et særtræk ved den danske og norske politiske tænkning - men ikke i nær samme grad den svenske og holstenske - at det aristokratiske ikke nød nogen særlig positiv opmærksomhed. Det hørte til den oldenborgske enevældes legitimeringsstrategi og administrative praksis at undergrave fødselsadelens privilegier, og man skal ikke undervurdere betydningen af, at både tilhængerne af det monarkiske princip og unge liberale brushoveder delte modstanden mod hhv. foragten for aristokratiet, fordi det stod i modsætning til enevældens centralisme og det for både enevælden og de liberale så afgørende meritokratiske princip. ${ }^{29}$ Denne foragt for aristokratiet var almindelig udbredt i hele Europa, men den kunne i andre lande opvejes af adelens ikke ubetydelige politiske og/ eller økonomiske magt. I Norge var denne magt så godt som ikke-eksisterende og i Danmark betragteligt indskrænket. Ikke mindst med dette delte fjendebillede kunne der i det 19. århundrede opretholdes en forestilling om enten en alliance eller en balance mellem det monarkiske princip og folkesuveræniteten i Danmark med et indskudt aristokratisk element, en slags lokal variant af monarchia mixta.

Ola Mestad har vist, hvordan den dansk-norske enevælde blev tolket naturretlig, altså som et resultat af en kontraktlig aftale mellem folket og kongen i $1660-61$, og at man i 1814 i overensstemmelse hermed fortolkede det således, at suveræniteten blev givet tilbage til folket. $3^{\circ}$ Det er

28. Om den blandede forfatning se M. H. Hansen, Demokratiets historie fra oldtid til nutid, Kbh. 2012: $28 \mathrm{ff}$.

29. Fx H. N. Clausen og J. F. Schouw, Ved Thronskiftet I848, Kjbh. 1848: 9 (Clausen) og især s. 4.4 (Schouw) Se Nevers, s. 97 .

3o. O. Mestad, Suvereniteten tilbakegitt det norske folk ved Kieltraktaten, Historisk tidsskrift $2014 / 1$. 
tvivlsomt, om folkesuverænitet var en del af tankegodset under statsomvæltningen 166o. Den er da også i klar uoverensstemmelse med enevældens egen forfatning, idet kontrakten ifølge Kongeloven selv var uopsigelig (art. III). Det nye var vel ikke folkesuveræniteten, men overhovedet ideen om suverænitet som noget, der begrebsligt lod sig adskille fra suverænen. Først senere blev ideen om det kontraktlige forhold mellem folk og konge introduceret som en legitimering af den bestående enevælde. At denne hjemmedyrkede amalgamering af enevælde og naturret mere end Rousseau har haft betydning for Eidsvollmændenes forestilling om folkesuverænitet er antagelig meget rigtig set, og denne indsigt åbner jo for en forståelse af begivenhederne i 1814, som udtryk for kontinuitet lige så meget som brud. Hvis monarkisk enevælde ikke udelukkede ideen om folkesuverænitet, udelukkede ideen om folkesuverænitet på den anden side heller ikke forestillingen om kontraktlighed mellem folk og konge.

Man finder den fx udtrykt i Eidsvollmændenes henvendelse til kongen den 17. maj, hvori de skrev, at hensigten var «at fordele den souveraine Magt saaledes, at Lovgivningen nedlægges i Folkets, og den udøvende Magt i Kongens Haand.» Det er et på interessant vis underbetonet element i den norske erindringskultur om Eidsvoll, at nationaldagen fejres på årsdagen for denne henvendelse. I sit svar nogle få dage senere anerkendte kongen visdommen i denne fordeling, fordi man dermed sikrede borgerfrihed og «den Orden i Staten, som den udøvende Magt er pligtig og formaaende til at vedligeholde.» Samtidig sikrede denne fordeling «at vogte Regjeringsformen for Despotismens Kjendemærker, og for Folkeregjeringens Misbrug.» ${ }^{1}$

Det er på denne baggrund den konstitutionelle debat efter 1814, skal ses. Der bestod ganske vist en teoretisk modsætning mellem folkesuverænitetsprincippet og det indskrænkede monarki, men i praksis blev begreberne ikke anvendt stringent. Endelig skal man ikke være blind for, at ideen om folkesuverænitet jo tjente planerne om norsk selvstændighed i 1814, væsentlig bedre end hvis man havde lagt vægt på Kielerfredstraktatens ord om at suveræniteten over Norge var monarkisk og kunne overdrages direkte fra den danske til den svenske monark. Derfor er det kun naturligt, at også prins Christian Frederik så muligheden i at bruge folkesuveræniteten som platform for opbygningen af sin kongeværdighed.

31. Kongeriget Norges Grundlov, Chria. 1814, trykt hos Jacob Lehmann: $38 \mathrm{f}$. Faksimile efter http://www.modern-constitutions.de/ nedtaget april 2014. Dette eksempel viser i øvrigt også, hvorledes denne reducerede udgave af den blandede forfatning ikke kunne tænkes uden en betydelig grad af funktionsdeling. 
Et nyt element i forfatningsdiskussionen var den hyppige anvendelse af ordet libérale..$^{32}$ Jörn Leonhard mener, at det som begreb anvendt i 1814 var løsrevet fra associationer til den franske revolution og kendetegnede politiske ønsker om reformer i almindelighed, og liberal «blev den fremherskende oppositionsetiket».33 Den iagttagelse bekræftes af den brug, som constitution libérale fik i den danske oversættelse. «En fri forfatning»" blev et begreb, der havde tilstrækkelig med prægnans og signalværdi til at fungere som emblem for ønsket om forbedringer i et samfund, der havde en meget klar oplevelse af at befinde sig i et tidehverv, i en overgangsfase mellem gammelt og nyt. ${ }^{34}$

Et af de afgørende resultater af Wienerkongressen var opretholdelsen af en mangfoldighed af tyske fyrstendømmer, der konsoliderede sig som konstitutionelle monarkier sammensluttet i det tyske forbund. I forbundsaktens Artikel 13 stod følgende bestemmelse «In allen Bundesstaaten wird eine landständische Verfassung stattfinden.» Der var ikke angivet nogen tidsfrist, og indholdet blev ikke nærmere specificeret, men bestemmelsen havde afgørende indebyrd for det danske monarki, idet både Lauenborg og Holsten indgik i det tyske forbund.

Forfatningsdiskussionen også i det oldenborgske monarki gik i gang med det samme. Allerede i 1816 havde Niels Falck, juraprofessor i Kiel, udgivet sine betragtninger om hertugdømmernes forfatningsretlige stilling, motiveret af ønsket om «Wiederherstellung der Landstände oder Einführung einer verbesserten Volksrepräsentation», en indirekte henvisning til forbundsakten. ${ }^{35}$ Indholdet af hans traktat gik stik imod den herskende opfattelse af især Slesvigs statsretlige status, og udfordrede endda det monarkiske princip, idet han mente, at det var de før-enevældige håndfæstninger, der skulle bestemme Slesvigs forhold til henholdsvis kongeriget og Holsten.

Uwe Jens Lornsens forfatningsudkast fra $183^{\circ}$ betragtes som startskuddet til liberalismens opblomstring, men der er grund til at gøre opmærksom på, at Lornsen ikke var uden forløbere som fx Falck. Også Lornsens skrift var udtrykkeligt motiveret af forbundsaktens for Holsten endnu uopfyldte 13. artikel, «worin die sämmtlichen Fürsten Deutsch-

32. B. K. Olesen, Frækhed er frihedens grænse, i O. Mestad 2013.

33. J. Leonhard, Liberalisme i det tidlige 19. århundrede: En historisk semantik i tysk og europæisk perspektiv, i J. Nevers, N. Olsen og C. Sylvest (red.), Liberalisme. Danske og internationale perspektiver, Odense 2013: $7^{8-79}$.

34. En af de tidligste forekomster af begrebet på dansk findes i J. Møller, Om Videnskabelighed og Moralitet, Theologisk Bibliothek, bd. 9, 1816: 73 .

35. Dr. N. Falck, Das Herzogthum Schleswig in seinem gegenwärtigen Verhältnis zu dem Königreich Dänemark und zu dem Herzogthum Holstein, Kiel 1816: 3 . 
lands ihren Ländern repräsentative Verfassungen zusichern», som han udlagde teksten. ${ }^{36}$

Presset på Frederik VI for at indføre en forfatning kom imidlertid ikke blot fra syd, men også fra nord. Den levende, norske forfatningsdiskussion kunne slet ikke forholdes den danske, læsende offentlighed. Den mest betydningsfulde nationalliberale politiker, juristen Orla Lehmann, skrev i 1834, en længere anmeldelse af Frederik Stangs Systematisk Fremstilling af Kongeriget Norges constitutionelle eller grundlovsbestemte Ret. En sådan anmeldelse var en glimrende anledning for den unge Lehmann til indirekte at give udtryk for sine statsretlige opfattelser som sådan. Lehmanns sympati var ganske klart i folkesuverænitetens favør, og han mente, at ingen konstitutionel konge kunne hævde sin selvstændige vilje "imod Folkerepræsentationens Villie". Derfor var diskussionen om, hvorvidt en konge skulle have suspensivt eller absolut veto over for parlamentet rent teoretisk, idet et eventuelt veto i praksis altid ville være midlertidigt. Kongens magt var og burde være indskrænket til at være administrativ:

Statsmagtens Fordeling imellem den monarkiske og demokratiske Myndighed kan kortest betegnes derved, at hele Administrationen tilkommer hiin, hvorimod Lovgivningen, Raadigheden over alt det Finantsielle og Regjeringens Controllering tilfalder denne. ${ }^{37}$

Der var altså ingen tvivl om, at magtbalancen mellem konge og parlament for Orla Lehmann måtte og burde falde ud til folkerepræsentationens fordel. I den anden ende af samme skala befandt N. F. S. Grundtvig sig. Han tilhørte den politiske fløj, der ikke ønskede anden indskrænkning i monarkiet end fuld skrive- og trykkefrihed. Hans argument var historisk, idet han kunne opremse alle de tilfælde, hvor en republikansk eller demokratisk forfatning havde bragt et land i ulykke. Han mente ikke, at menneskeheden var vokset således i moral og dannelse, at der var grund til at knytte håb til nogen form for demokrati, og han ironiserede over de forhåbninger, som opinionen nærede til mængden og fornuften:

Naar jeg derfor hører og læser om al den Lykke og Velsignelse der skal falde ned fra Skyerne, hvor Regierings-Formen bliver saa demokratisk som mueligt, altsaa enten pøbel-parisisk eller kræmmer-amerikansk, da kan jeg, hvor det synes ærlig meent, og ei er unge Fusentaster som udmale deres Drømme, kun forklare mig det af den herskende Over-Tro

36. U. J. Lornsen, Über das Verfassungswerk in Schleswigholstein, Kiel 18zo: 3.

37. O. Lehmann, anm. af F. Stang, Systematisk Fremstilling af Kongeriget Norges constitutionelle eller grundlovsbestemte Ret, Maanedsskrift for Litteratur, 12. bd., 1834: 305. 
paa en vis luftig Vor-Herre, ved Navn Fornuften, som Man har den Indbildning om, at, om ikke just hvor To eller Tre, saa dog hvor to eller tre Hundrede er forsamlede i hans Navn, der vil han selv være midt iblandt, og med ubegribelig Almagt styre det saa, at skiøndt Vankundighed og Selv-Klogskab parres hos de Fleste, bliver dog Udfaldet Viisdom, skiøndt den almindelige Selv-Raadighed forstyrrrer al Sammen-Virkning, opstaaer dog den ønskeligste Enighed, og skiøndt de Enkeltes Egen-Nytte ligger i aaben Feide med det Heles Velfærd, blomstrer dog Samfundet som en Rose. ${ }^{38}$

Erfaringen viste, mente Grundtvig, at hvis monarken viste sig at være despot, ville despotiet dog ophøre med hans død, mens et despotisk folkestyre ville være «det gruelige Uhyre, med utallige Hoveder, som aldrig faae Ende». 39 Han sluttede sine politiske betragtninger med et ønske om, at de gode tider ville vare ved:

Saa lade da det naadige Forsyn, der saa uafladelig har vaaget over os, Danmarks Historie til Verdens Ende klarlig bevise, at en enevældig Konge med et Landsfader-Hjerte, er Kilden til sand borgerlig Frihed og Lyksalighed, mens der er kun alt for mange Riger, hvis Historier aabenbare, at en Rigs-Dag med en Skygge-Konge er en virkelig og stor Ulykke. ${ }^{40}$

Frederik VI imødekom forbundsaktens krav om repræsentation ved at indføre provinsialstænderforsamlinger med Preussen som forbillede. Repræsentationen i disse var i høj grad korporativ, men de blev i stigende grad præget af den nationale tanke. For den politiske kultur havde de afgørende betydning. Ganske vist var forsamlingerne kun rådgivende, men de udgjorde et legalt forum for politisk debat med en rækkevidde langt ud over de stænderdeputeredes egne rækker, idet referaterne blev refereret og udgivet.

Stænderforsamlingerne tilfredsstillede ikke ønsket om en «fri forfatning». Det er som nævnt ikke ganske klart, hvad der mentes med dette begreb, men det synes først og fremmest at have haft den førnævnte emblematiske effekt, der kunne virke samlende for alle dem, der ønskede forandringer, uden at det altid måtte ekspliciteres, hvori disse forandringer skulle bestå. Det var en måde at undgå splittelse blandt dem, der ønskede en fri forfatning. Væsentlige elementer synes at have været lovfæstet ytringsfrihed, ministeransvarlighed og afløsning af kollegial-

38. N. F. S. Grundtvig, Politiske Betragtninger med Blik paa Danmark og Holsteen, Kjbh. 1831: $7^{2}$.

39. Grundtvig 1831: 55 .

40. Grundtvig 1831: 22. 
styret, et åbent og gennemskueligt statsregnskab, repræsentative forsamlinger med indflydelse på finansvæsenet og lovgivning og almindelig eller lige værnepligt. ${ }^{41}$

Der var knyttet håb til, at Christian VIII ved sin tronbestigelse ville imødekomme ønskerne om en friere forfatning, fordi han havde stået fadder til Eidsvollforfatningen. I litteraturen beskrives han ofte som en skuffelse. Det er ikke en ganske retfærdig dom. Han videreførte i sine første regeringsår en gennemgribende kommunalreform, der gav borgere og jordejere en betydelig andel i sognekommunernes og købstædernes bestyrelse, og i 184,1 udkom det første samlede statsbudget på tryk. Når kongen ikke kunne imødekomme ønsket om en fælles forfatning for sit monarki, var det naturligvis fordi det slesvigske problem stod i vejen. Det skal ikke nærmere afhandles her.

I 1841 udkom den norske jurist, O. Munch-Ræders (1815-1895) bog om den norske forfatning. Den blev udgivet i København, måske fordi hans synspunkter kunne forekomme kontroversielle hjemme i Kristiania og ikke mindst i Stockholm. Hvorom alting er, fik bogen et dansk publikum, og den blev da også anledning til en fornyet debat om en fri forfatning. Munch-Ræder er et eksempel på en næsten entydig positiv anvendelse af begrebet demokrati, og han betegnede interessant nok den norske styreform som «indskrænket Demokrati». ${ }^{42}$

Han er interessant, fordi han som en af de få forholdt sig direkte til det indskrænkede monarki som princip. Han lagde vægt på, at Eidsvollforfatningen byggede fuldstændig på folkesuverænitetens princip. Denne ret skarpe tolkning skal antagelig også ses i lyset af hans egen samtid. Mens valget af en norsk konge i 1814 var omdrejningspunkt for norsk selvstændighed, var den svenske unionskonge i 184,1 symbol på det modsatte. ${ }^{43}$ Det var derfor Munch-Ræder meget om at bortforklare forfatningens monarkiske element:

Den norske Statsforfatning er ifølge Grundlovens $§ 1$ indskrænket og arvelig monarkisk. Denne Betegnelse er neppe den nøiagtigste; thi den synes at antyde, at det monarkiske Element er det principale, og at det kun taaler Folkemagten ved sin Side; man skulde troe, at Monarken har opgivet noget af sin primære Magt og Myndighed, og overladt nogle Smuler af sin Suverænitet til Folket. Det er imidlertid misledende at betragte Forholdet saaledes; thi den demokratiske Magt, som igjennem

4.1. Se f.eks. H. N. Clausen og J. F. Schouw, Ved Thronskiftet 1848 , Kjbh. 1848: $4^{2}, 73$ og 78 .

42. O. M. Munch-Ræder, Den norske Statsforfatnings Historie og Veesen, Kjbh. 184,1: 36 . Se fx s. 8 , noten og s. 33 .

43. Se R. Glenthøj, Skilsmissen. Dansk og norsk identitet før og efter I8I4, Odense 2012: $149 \mathrm{ff}$. 
Rigsforsamlingen paa Eidsvold grundlagde Norges Statsforfatning, og som heri virkede med aldeles uindskrænket Myndighed, glemte ikke at forbeholde sig selv de dominerende Drivhjul i det konstitutionelle Maskineri. Den kongelige Værdighed, som siden Kong Frederik den Sjettes Aftakkelse ikke havde existeret i Landet, blev vel gjenoprettet; Folkets Traditioner og dets dermed sammenknyttede Overbeviisning gjorde det passende og nødvendigt at gjernrejse Norges gamle Kongestol. ${ }^{44}$

Munch-Ræder var tæt på at mene, at kongen nærmest kun havde symbolsk betydning, og han var ingen ynder af den udbredte «Lære om Nødvendigheden af Statsmagtens Ligevægt», og han betragtede af samme årsag det suspensive veto (\$79) som forfatningens «meest funklende Edelsteen». ${ }^{45}$

Det var i en dansk kontekst i 1840 'erne en ret radikal opfattelse af kongens rolle, og Munch-Ræders bog gav anledning til en genopblussen af forfatningsspørgsmålet i Danmark..$^{46}$ Et af de kendteste indlæg i den debat var en tale, som Orla Lehmann holdt på Falster i 1841. Han henviste ikke direkte til Munch-Ræder, men inddrog den norske forfatning som forbillede, idet han opfattede Christian VIII som Eidsvollforfatningens giver. Det var en tolkning, der tillod ham knytte bånd mellem den eksisterende enevælde og den af ham ønskede forfatningsreform. Lehmann talte til en gruppe bønder, og det var hans væsentligste ærinde at vise, at enevælden ikke var i bøndernes interesse. Ganske vist havde Frederik VI gjort meget godt, men det beroede på kongens person og ikke systemet. Lehmann krævede en fri forfatning som den norske:

Ville Bønderne derfor sikkre sig baade at beholde hvad de have opnaaet, og at opnaa, hvad de endnu retfærdigen kunde ønske, da maa de sætte deres Haab til en fri Forfatning. ... Se Dem dog om! Er det blandt Venner af Enevælden eller blandt Vennerne af en fri Forfatning, - er det f.Eks. blandt de høje Herrer ved Hoffet eller blandt de ilde ansete Bladskrivere, at Bondens Vel finder sine varmeste Talsmænd? Og se Dem om i en videre Kreds! Have maaske de norske Bønder havt Skade af den frie Forfatning, hvilken vor nuværende Konge som Prinds har skaffet dem?47

Talen kostede Lehmann en fængselsstraf, fordi han kritiserede enevælden, men faktisk lagde han stor vægt på at understrege over for sine til-

\footnotetext{
44. Munch-Ræder 184,1: $3^{1 .}$

45. Munch-Ræder 184,1: 4,2 og 4,o.

46. D. C. Christensen, En analyse af hovedpunkter i forfatningsdiskussionen i Danmark I83oI849, upubl. prisafhandling, Københavns Universitet 1969: 66.

47. C. Ploug (udg.), Orla Lehmanns efterladte Skrifter, Tredje Del, Kjbh. u.å.: 120-121. Nevers tolker den på samme måde, s. ıoıf.
} 
hørere - og senere over for dommerne i retssagen - at han ikke ønskede at fratage kongen enhver magt:

Alt hvad jeg har sagt, gaar ud paa at vise, at det aldeles ikke er Meningen, at tage nogen god og ønskelig Magt fra Kongen. Tvertimod - jo større Magt Folket faar, desto større Magt faar ogsaa Kongen; thi Kongen og Folket ere Eet, og kun den Konge, som har et stærkt Folk, kan selv være stærk..$^{4}$

Den væsentligste beføjelse, som et «Folkeraad»skulle have ifølge Lehmann var skattebevillingsretten - «Hjørnestenen i enhver fri Forfatning»: «Den Haand, som aabner og lukker for Folkets Lomme, det er Folkets udkaarne Mænd - de ere de bedste Skatmestere» (s. 125). Folket ville jo ikke kaste penge ud til den overflødighed af slotte, som Nordsjælland er oversået med og folket ville heller ikke forsørge «alle de tydske Smaaprindser, Projektmagere og Vagabonder, der som graadige Ravne kastede sig over det stakkels Land». Den nationalliberale demagog var i fin form på Falster. Hvorvidt Lehmann selv troede fuldt og fast på det, han sagde, eller om hans ord var målrettet publikum er ikke så væsentligt. Under alle omstændigheder var talen udtryk for, at der var et publikum til den opfattelse, at konge og folkeråd skulle balancere.

Grundtvig talte også på dette tidspunkt varmere om enevælden som styreform, men stadig ud fra den samme grundlæggende forestilling om, at et retfærdigt styre var en afbalancering af kongemagt og folkemagt. Grundtvig var også meget opmærksom på udviklingen i Norge og England.

At bevilge Skatter er vist nok en gammel Folke-Rettighed og lader sig godt forene med saa megen Magt hos Kongen, som han for sin Person kan nøjes med; men især Englands Eksempel skal lære os, at naar kun Folke-Stemmen ved alle ny Paabud raadspørges, da er Riget bedst tjent med, at Kongen har den afgjørende Stemme. ${ }^{49}$

Grundtvig ville lade kongen beholde lovgivningsretten. Med henvisning til «den parisiske Pøbel i Rædsels-Tiden» stillede Grundtvig sig tvivlende over for det hensigtsmæssige i at «det engelske Parlament eller det norske Storting giver Love», idet han bemærkede, «at jo flere Lovgivere der er i et Land, des flere personlige Hensyn og des flere personlige Fordomme maa man vente, gjør sig gjældende..$^{5^{\circ}}$

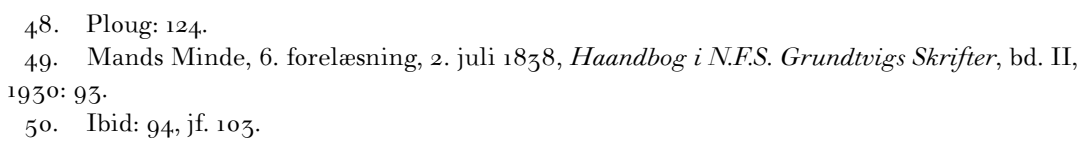


Grundtvigs ideal var en frit handlende kongemagt stillet over for en frit stillet folkestemme, det vil sige trykke- og talefrihed, et ideal han så virkeliggjort i de rådgivende stænderforsamlinger. Derimod var han imod det, «som Latinerne kalde det repræsentative System», fordi det fremmede repræsentationen af interesser, hvor folk gør «en Pung af deres Mund»..$^{1}$

Det er blevet fremhævet som et særligt træk ved Grundtvig, at han ikke var demokrat - i modsætning til Orla Lehmann. Men for det første delte Grundtvig sin skepsis over for flertalstyranniet med mange af sine samtidige. Lehmann selv var også ganske elitær og opfattede heller ikke folkeflertallet som repræsentativt for folkets sande interesser. Lehmann og Grundtvig havde lige så lidt som de fleste af deres samtidige til hensigt at indføre demokrati i nogen moderne forstand. Diskussionen stod blot om, hvor megen vægt det demokratiske eller repræsentative element skulle have i en forfatning.

Og Grundtvig var som ovenfor vist enig med Lehmann i, at skattebevillingsretten tilhørte folket. På andre punkter kunne de være uenige om, hvordan magten skulle fordeles mellem folkeråd og konge, men ikke at den skulle fordeles mellem folkeråd og konge. Grundtvigs forståelse af forfatningen var mere organisk end Lehmanns. Lehmann var ikke for ingenting jurist. Han havde et mere hands-on forhold til magten og dens udøvelse. Grundtvig var mere sværmerisk, men insisterede i lighed med Lehmann på borgerlige rettigheder.

Andre deltagere i den konstitutionelle debat i 1840'erne bevægede sig på samme skala som Grundtvig og Lehmann. Meget få forsvarede absolutismen i ren form, men det monarkiske element i en kommende forfatning blev tillagt skiftende grader af værdi. A. S. Ørsted var bekymret for at give «det demokratiske Element» for stor værdi, og han mente, at suveræniteten skulle forblive hos kongen. ${ }^{52}$ Det kan næppe kaldes et overraskende synspunkt for en af kongens mest fremtrædende embedsmænd. Også P. G. Bang mente, at kongen skulle bevare suveræniteten, altså kontrollen med militæret og politiet. P. A. Tutein gik ind for en afbalancering af kronen, førstekammeret og andetkammeret, og H. N. Clausen mente tilsvarende, at regeringen måtte bygge på en forening af alle kræfter, et «juste-milieu».53

Presset steg på Christian VIII gennem 1840erne. I 1847 var kongen

51. N. F. S. Grundtvig, Det danske Fiir-Kløver (1836), i Smaaskrifter om den historiske Høiskole, Kjbh. $1872: 26$.

52. D. C. Christensen 1969: 78 .

53. D. C. Christensen 1969: 81 . 
ikke engang tæt på at indføre reformer, der kunne tilfredsstille de nationalliberale krav. Da det tidligt i januar 184,8 stod kongen klart, at han skulle dø, vidste han også, at det dynastiske problem som følge af hans død ville gøre den politiske situation endnu mere anspændt, så han skrev et politisk testamente til sin søn, i hvilket han pålagde ham at gifte sig standsmæssigt, det vil sige løse det dynastiske problem, og endvidere «ved sin Regierings Tiltrædelse at tilsige det danske Folk og Hertugdømmerne en fælles constitutionel Forfatning, som han forbeholder nærmere at give disse hans Arvelande».

Det var et eklatant udtryk for, at kongen efterlod sig en opgave, som han ikke selv havde magtet at løse. Den gordiske knude bestod i, at den konstitutionelle bevægelse havde knyttet sig stærkt til den nationale, kravet om Danmark til Ejderen gik hånd i hånd med kravet om en fri forfatning. De nationalliberale ønskede sig måske ikke et demokrati, men man kan godt beskrive deres ambitioner som et ønske om at indføre konstitutionelt etnokrati. Det vil sige, at ethvert forsøg på at give Helstaten en fællesforfatning ville møde modstand fra de nationale bevægelser.

Christian VIII selv havde forestillet sig et Statsråd efter preussisk forbillede, altså en gruppe udpeget af ham selv, en slags kongeligt senat med lovgivende og dømmende myndighed. ${ }^{54}$ Tanken om en fælles forfatning for alle rigets dele blev ofte formuleret som en plan om et fællesorgan for de fire stænderforsamlinger. For nylig har Thomas Riis fremdraget et anonymt udkast fra de tidlige måneder af 1848 til en stænderordnet fællesforfatning, der antagelig hører til samme store gruppe af fejlslagne forsøg på at få ordning på forfatningsproblemet. 55

Christian VIII's død og de efterfølgende begivenheder i det tidlige forår 184.8 annullerede en stor del af de lagte planer og forcerede processen i retning mod en skærpelse af de konflikter, der udsprang for det første af spørgsmålene om hertugdømmernes forhold til hinanden og til kongeriget og for det andet af det krav om en fri forfatning, der i lyset af den europæiske kontekst antog en stadig tydeligere karakter af revolutionær trussel. Hans Vammen har vist, hvordan Orla Lehmann ved at spille på begge disse konflikter eller trusler fik fremtvunget et regeringsskifte i marts $184.8 .^{5}$ Truslen om revolution anvendte han helt åbenlyst, men førte den ikke ud i livet. Derimod kunne han ikke tøjle de nationale kræf-

\footnotetext{
54. N. Petersen (udg.), Betcenkninger fra Christian VIII's tid om styrelsen af det danske monarki, Kbh. 1969 : xvii. Heri også det politiske testamente: 365 .

55. S. Loebert, Entwurf einer Verfassungs-Urkunde für das Königreich Dänemark und die Herzogthümer Schleswig und Holstein, i Loebert/Meiburg/Riis (Hrsg.), Die Entstehung der Verfassungen der dänischen Monarchie (I848-I849), Frankfurt/M 2012.

56. H. Vammen, Casino 1848 , (dansk) Historisk Tidsskrift, 1988.
} 
ter, som han selv havde sluppet løs. Udbruddet af den første slesvigske krig fulgte som logisk resultat.

Hvorom alting er, blev det også en konsekvens af regeringsskiftet, at et udvalg blev sat til at skrive et udkast til en forfatning med D. G. Monrad som pennefører. ${ }^{57}$ Grundlovsudkastets første paragraf, hvor formuleringen om det indskrænkede monarki forekommer, levede ingen stille tilværelse i det arbejde, men det skyldtes, at den også rummede redegørelsen for, hvilket geografisk område loven var tænkt at dække. Debatten herom var ikke mindst påvirket af, at der samtidig blev udkæmpet en krig om netop dette spørgsmål. Derimod var der meget begrænset interesse for at diskutere princippet om det indskrænkede monarki. Forbilledet var som nævnt Eidvollforfatningens $\$ 1. Især den belgiske forfatning udgjorde et forbillede for Monrads oprindelige forfatningsudkast. ${ }^{5^{8}}$ Men i debatten i den grundlovgivende rigsforsamling var Norge, Frankrig og England de lande, der oftest blev nævnt. ${ }^{59}$

Formuleringen passerede gennem både udvalg og den grundlovgivende rigsforsamling næsten upåtalt. ${ }^{60}$ Der blev stort set ikke sat spørgsmålstegn ved den. En undtagelse var den kongeligt udpegede og meget monarkisk sindede P. B. Scavenius, der ønskede helt at slette de første paragraffer, fordi han mente, at de i virkeligheden gjorde kongen magtesløs og indførte «Quasirepublik». ${ }^{61}$

Hovedindtrykket af forhandlingerne på den grundlovgivende rigsforsamling er et udbredt og ofte gentaget ønske om at ville indskrænke, men ikke krænke det monarkiske princip. ${ }^{62}$ Der synes at ligge to forhold i det. For det første ønskede man ikke, at kongemagten skulle udvikle sig til en «Skinkonge», «hvis politiske Liv næsten kun var at deeltage i Processioner». ${ }^{6} 3$ For det andet byggede det på ligevægtsteorien, altså at magten var delt og at dens udøvelse krævede en afbalancering.

57. P. Bagge, Studier over D.G. Monrads Statstanker, Kbh. 1936: 43f.

58. P. Munch, Monrads Udkast til Grundloven, (dansk) Historisk Tidsskrift, bd. 8, 4. Rk., 1912. K. Hvidt, Grundlovens historie, i H. Zahle 20o6: 3. Helt upåagtet er det, at $\$ \$ 86$ og 87 i junigrundloven er næsten ordret sammenfaldende med de tilsvarende paragraffer i den preussiske forfatning af dec. 184.8. Se Beretning om Forhandlingerne paa Rigsdagen, bd. 2, Kjbh. 184,8, sp. 2169 . Der er også flere verbalsammenfald med det preussiske forfatningsudkast af maj 184,8 , fx $\S 9^{1}$ om trykkefrihed.

59. En optælling bygget på søgning i den elektroniske fuldtekstversion af forhandlingerne (se næste note) giver følgende antal hits: Slesvig 175, Frankrig 170, England 130, Norge 120, Tydskland 43, Preussen 4.0, Sverige 37 og Belgien 25.

6o. Der citeres fra Beretning om Forhandlingerne paa Rigsdagen, bd. 1-2, Kjøbenhavn $184.8-$ 1849. Til søgninger er anvendt http://grundlov.dab.dk/. Ørsted er en af de få, der ytrer tvivl om, hvorvidt regeringsmagten skulle være kongens: sp. ${ }^{564}$. Der henvises til spaltenumre.

61. Forhandlingerne på den grundlovgivende rigsforsamling, sp. ${ }_{7} 89$ (sic!), $179^{1-} 9^{2}$ og 2739 .

62. Ibid sp. 1582, 1626, 3180, 2064 .

63. Ibid sp. $1795^{-} 96$, udtrykket her gengivet på 2. hånd. 
Ordfører for Rigsforsamlingens grundlovsudvalg, professor A. F. Krieger var en af dem, der ekspliciterede princippet, og hos ham finder man tydeligt genklangen af den klassiske blandede forfatning:

Jeg troer, at Magten ikke alene kan, men skal deles, og at, hvis den ikke deles, da vil det føre til Despoti, hvad enten man har et Monarki eller en Republik; Forskjellen er da ikke mellem Monarki og Republik, men mellem det constitutionelle, være sig Monarki eller Republik, og det despotiske, være sig Monarki eller Republik. ${ }^{6}$

Også historikeren Frederik Schiern understregede nødvendigheden af en selvstændigt virkende, stærk og uafhængig regering:

Thi Enhver af os bedømme Forholdet mellem den monarkiske og den republikanske Regjeringsform, som han vil, afgjort bliver det dog, at

Danmark trænger til en stærk, uafhængig, ikke servil, udøvende Magt. ${ }_{5}$

Med forfatningen blev det dynastiske princip opgivet. A.F. Tscherning redegjorde for, at staten med grundlovsbestemmelsen om tronfølgen ikke længere kunne anses som monarkens ejendom, men at monarken nu blev udpeget af staten. ${ }^{66}$ Spørgsmålet var jo aktuelt, fordi Frederik VII's barnløshed var blevet et meget påtrængende problem.

Kongen blev opfattet som grundlovens giver, men netop i kraft af hans barnløshed var dette aspekt af det monarkiske princip ikke af en betydning, der rakte videre end kongens levetid. Det var i virkeligheden et stykke ad vejen en gratis omgang at gøre knæfald for monarken på denne måde. Skal man tale om en undergravning af det monarkiske princip, skal man ikke søge den i det demokratiske princip, men først og fremmest i det forhold, at Rigsdagen - ganske vist under pres fra det europæiske pentarchi - i 1853 vedtog en ny tronfølgerlov og dermed ændrede magtbalancen mellem forfatningens demokratiske og monarkiske element.

\section{MINISTERANSVARLIGHED}

Den endelige grundlov endte som nævnt med at definere styreformen som indskrænket monarkisk, formelt set monarchia limitata.

Paragraf to af junigrundloven definerede yderligere de indskrænk-

64. Ibid sp. 1799-18oo, se også sp. 1993 (korrektur, sp. 2036): «Opgaven for Tokammersystemet i en monarkisk Forfatning er netop at gjøre det muligt, at en klog og dygtig Regjering kan bestaae ved Siden af en Folkerepræsentation». Se også sp. 2107 og 274.1 om magtens deling mellem konge og folk.

65. Ibid sp. $295^{8 .}$

66. Ibid sp. $15^{81}$. 
ninger, der skete i kongens enevældige magt: «Den lovgivende Magt er hos Kongen og Rigsdagen i Forening. Den udøvende Magt er hos Kongen. Den dømmende Magt er hos Domstolene.»

Paragraffen står uændret og udlægges i dag som en forskrift for den funktionelle tredeling af magten. Som sådan er der tale om en uklar formulering, men læst i sin oprindelige kontekst er den meget klar: Kongen måtte helt opgive sit forsæde i Højesteret. Det havde han ganske vist ikke gjort anvendelse af i praksis siden 1740'erne, og det danske retsvæsen havde allerede inden 184,8 udviklet en betydelig grad af selvstændighed i forholdet til kongemagten. ${ }^{6}$ Kongen kunne dog stadig benåde. Til gengæld beholdt kongen den udøvende magt, mens han måtte dele den lovgivende med Rigsdagen. Kongen kunne opløse Rigsdagen eller hvert af tingene (\$27), og hans samtykke krævedes for at en lov skulle have gyldighed (\$ 29). Kongen kunne endvidere i nødstilfælde give foreløbige love $(\$ 30)$.

Det er denne opdeling af kongens magt, der kan give anledning til at hævde, at junigrundloven faktisk er en slags blandet forfatning med kongens og hans ministre som det monarkiske element, Folketinget som det demokratiske og Landstinget som det aristokratiske element. Det er imidlertid en pointe, der med få undtagelser er fuldstændig fremmed for danske historikere. ${ }^{68}$ Det må imidlertid stå klart, at sådan var den også tænkt fra grundlovsfædrenes side. Spørgsmålet bliver derfor, hvordan man havde forestillet sig et samvirke mellem Rigsdagen og regeringen.

Kongen førte regeringen gennem sine ministre. ${ }^{69}$ Junigrundlovens $\$ \$ 18$ og 19 fastslog, at kongen var ansvarsfri og ministrene ansvarlige. Det er især disse formuleringer, der har fået mange til at udlægge junigrundloven som om den i virkeligheden var parlamentarisk, altså at $\S_{2}$ slet ikke skal tages alvorligt. Det skyldes, at man i dag fortolker dette ansvar som et politisk ansvar, altså at ministrene står til ansvar over for Rigsdagen. Dette ansvar var i junigrundlovens ånd blot af en helt anden beskaffenhed end det, der gør sig gældende under parlamentarismen. $\$ 20$ forklarer:

67. H. Jørgensen, Trykkefrihedsspørgsmaalet i Danmark 1799-1848, Kbh. 1944.

68. S. Olden-Jørgensen, Prinsessen og det hele kongerige, Kbh. 2003: 57. Se også P. Svensson, Blev der indført demokrati i Danmark i 1849 ? Temp nr. 7, 2013: 169. J. Wendel-Hansen, Ludvig Holstein-Ledreborg og folketingsparlamentarismen, (dansk) Historisk Tidsskrift 2013/2.

69. I det førnævnte anonyme forfatningsudkast, der blev til kun få måneder før Monrads, er princippet i det indskrænkede monarki defineret i artikel 3 uden dog at selve begrebet blev anvendt: «Der König vereinigt in Seiner Person die gesammte Regierungs-Gewalt, in soweit ihre Ausübung nicht durch den Inhalt der Verfassungs-Urkunde beschränkt wird.» Loebert/ Meiburg/Riis 2012: 207. 
«Ministrene kunne tiltales for deres Embedsførelse. Folkethinget anklager, Rigsretten dømmer.»

Det vil sige, at det ansvar, som ministrene havde, var juridisk, ikke politisk. ${ }^{\circ}$ Ministrene var i grundlovens forstand ikke politikere, men embedsmænd. Det var derfor de bar uniform på samme måde som alle de øvrige embedsmænd, der blev udnævnt af kongen. For disse højeststående embedsmænd var der imidlertid blot indrettet en særlig domstol. Med Hother Hages ord vælger og afskediger kongen sine ministre, «men disse og ikke han administrere. Feilene, der begaaes, er Ministrenes og ei Monarkens, hine maae altsaa ogsaa bære Ansvaret.» ${ }^{11}$

Den gennemsete grundlov af 1866 bliver som regel fremstillet som udtryk for en stærk konservativ reaktion. Niels Clemmensen har imidlertid gjort klart opmærksom på, at det konservative element allerede var stærkt i den grundlovgivende rigsforsamling. ${ }^{72}$

1866-grundloven medførte en kalibrering af balancen mellem statsstyrets elementer til fordel for det aristokratiske element, idet valgreglerne styrkede det store hartkorns adgang til Landstinget. Det var ikke et forsøg på at genoplive den gamle fødselsadels privilegier, alene af den grund at mange af de førende skikkelser blandt godsejerne slet ikke var adelige. Argumentet var, at de, der ejede meget store dele af jorden, både kunne og måtte bære ansvaret for statens styrelse. ${ }^{73}{ }_{1866} 8$-grundloven fik tilføjet en paragraf, der styrkede det monarkiske element, idet det nu blev ekspliciteret, at kongen med de i denne grundlov fastsatte indskrænkninger har den højeste myndighed over alle rigets anliggender og udøver den gennem sine ministre, som det fortsat hedder i den nuværende $\$ 12$. Den indebar dog ingen praktiske ændringer. Junigrundloven havde ikke forudset, at kongen førte forsædet i Statsrådet. Det blev dog fast praksis fra $185^{2}$ og fastholdt i 1866 -grundlovens $\$ 15$, nuværende $\$ 17$. Til gengæld blev bestemmelsen om, at kongen har den højeste myndighed over sø- og landstridskræfterne taget ud af $\$ 18$ i 1866.

Revisionens arkitekt, Estrup, er blevet bebrejdet, at han ikke løste det problem, der opstod, hvis der var uoverensstemmelse mellem Rigsdagens to kamre eller mellem Rigsdagen og regeringen. Men pointen er, at det slet ikke var hensigten med reformen at tilvejebringe et hierarkisk for-

\footnotetext{
7o. Se J. P. Christensen, Ministeransvar, Kbh. 1997: kap. 3 .

71. H. Hage, Ministeransvarlighed, Tokammersystemet og Valgloven, Kjbh. 1848: 17.

72. N. Clemmensen, Fra Junigrundlov til revideret Junigrundlov 1849-1866, Den jyske Historiker, nr. 83/84, 1999: 182 .

73. J. Wendel-Hansen og J. F. Møller, Bound to the State - The Nobleman in Danish Politics, Journal of Modern European History, 11, 2013/4.
} 
hold mellem statsstyrets elementer. Det aristokratiske blev styrket, men der var fortsat ikke reguleret, hvorledes konflikter skulle afgøres. Det var bevidst fra Estrups side. Det var hans opfattelse, at interessemodsætninger og konflikter skulle afgøres ved hjælp af afbalancering, og at man ved forhandling mellem ligeberettigede faktorer skulle nå resultater. ${ }^{74}$

Estrups ideal om et imødekommende samarbejde mellem magtens indehavere repræsenterer et syn på magtens udøvelse, der på sin vis udgør en hovedstrøm i dansk politisk kultur. Det er drømmen om, at magt kan udøves, uden at nogen skal trynes, forestillingen om at politikere må kæmpe med ord og ikke med sværd, også i overført betydning. Estrup havde ikke meget tilovers for masserne. Flertallet havde ikke ret, bare fordi det var et flertal. Estrup har bestemt ikke været alene om at mene, at «den Paastand, at det altid er Flertallet, der har ret», er «en Uhyrlighed», og at hvis flertallet får sin vilje hele tiden, er der tale om «et Diktatur fra Flertallets Side?. ${ }^{75}$ Det var ordret, hvad Hal Koch mente i 1945. Sammenligningen mellem Hal Koch og Estrup er naturligvis dristig, for de står sædvanligvis som modpoler, når man ridser det danmarkshistoriske politiske landskab op. Estrup var ikke demokrat, mens Hal Koch fejres som en af det danske demokratis intellektuelle fædre. Men fælles havde de en drøm om, at løsningerne allerbedst kunne tilvejebringes i enighed, at samfundets og almenvellets interesser var bedst varetaget ved, at alle parter blev taget med på råd.

Efter 1866 blev det klart, at idealet om et afbalanceret statsstyre var uholdbart i virkeligheden. «Balancen» viste sig at være en uafgjort magtkamp. Især den fraktion af politikere, som blev holdt fra magten i kraft af det system, grundloven havde skabt, blev modstandere af systemet. Da Venstre opnåede flertal i Folketinget, ønskede partiet et system, hvor Folketingets røst var afgørende. I 1873 fik dette system for første gang et navn på dansk, parlamentarismen. Det var D. G. Monrad, der brugte det i et brev til sin søn:

Det forenede Venstres Feldtraab er: en parlamentarisk Regjering, forstaaet saaledes, at det er Folkethingets Flertal, der bestemmer, hvem der skal være Ministre. Dette udtrykkes i Partisproget saaledes: der er en Sammensværgelse mod Folkethinget, og denne Sammensværgelse gaaer ud paa at berøve det al Betydning. Da jeg talte med Kongen, lod han til at være bestemt paa at være udholdende i sin Modstand mod

74. D. Tamm, Konseilspresidenten Jacob Brønnum Scavenius Estrup, Kbh. 1996: 255, sml. 170 .

75. H. Koch, Hvad er Demokrati?, Kbh. 1945: 20. Se også J. F. Møller, Hal Koch - en biografi, Kbh. 2009: 208ff. 
Parlamentarismen, der jo rigtignok ogsaa passer meget slet til vore Forhold. ${ }^{76}$

Det, der skete i 187 oerne var ikke, at Højre forvanskede en eksisterende grundlovstolkning, så den passede til den magtpolitiske situation. Det, der skete, var at Venstre forlod den indtil da dominerende ligevægtsteori og begyndte at stille krav om, at ministeriet måtte bøje sig for Folketinget. Det skete til at begynde med ikke i form af et programmatisk krav om en gennemgribende grundlovsreform, men som et ønske formuleret inden for rammerne af teorien om statsmagtens ligeværdige og afbalancerede parter - i den givne politiske diskurs, om man vil.

Denne diskurs er udtrykt meget godt i den erindringskultur, der voksede sig stærk især i venstrekredse. Mellem $185^{2}$ og 1891 blev der rejst mindst ${ }_{4} 6$ monumenter til ære for Frederik VII, mange med påskriften «Grundlovens Giver», mest kendt er rytterstatuen foran Christiansborg i København. ${ }^{77}$ De er symbolske anerkendelser af, at junigrundloven netop ikke bygger på folkesuverænitetsprincippet, men var en oktrojeret forfatning. Det bliver meget tydeligt, når man sammenligner med Norge, hvor det første monument over Christian Frederik blev rejst i maj 2014 . Sammenligningen bliver så meget desto mere interessant, når man ser på forskellen mellem fader og søn i praksis. Christian Frederik, den senere Christian VIII, var en kompetent politisk aktør, der tilvejebragte muligheden for, at Norge overhovedet fik en forfatning, mens hans søn var en svag aktør, der blot gav efter for folkestemningen. Alligevel er det junior, der huskes som «Grundlovens Giver». Hvis titlen skulle gives for personlig indsats, tilhørte den givetvis faderen.

På Rigsdagen herskede endnu o. 1870 opbakning til det monarkiske princip og ligevægtsteorien, også blandt medlemmer af oppositionen. I december 1873 vedtog Folketinget en adresse til kongen. Den var formet som en klage over, at modsætningsforholdet mellem regering og lovgivere havde stået $\mathrm{i}$ vejen for nødvendige forandringer:

Det er en Kjendsgjerning, vitterlig for Alle, at der alt i længere Tid har været en beklagelig Mangel paa god Samvirken mellem Folkethinget og Deres Majestæts ansvarlige Raadgivere. Følgen heraf har været en høist uheldig Stillestaaen i Lovgivningsarbeidet, som navnlig viste sig i forrige Samling, hvis Udbytte stod i et sørgeligt Misforhold til den derpaa

76. D. G. Monrad, Breve, udg. af S. Hauge, Kbh. 1969: 151. Udtrykket stammer fra engelsk, hvor det første gang blev udmøntet af Walter Bagehot i 1867 som «parliamentary system». Se også L. Tandrup, D.G. Monrads syn på konstitutionalisme og parlamentarisme, Historie - Jyske Samlinger, VIII, $1,1968$.

77. I. Adriansen, Erindringssteder i Danmark, Kbh. 2011: $216 \mathrm{f}$. 
anvendt Tid og Møie og til den fra alle Sider erkjendte Trang til en Omordning af vigtige Samfundsanliggender. Den herved fremkaldte Utilfredshed har bidraget til at forøge den Gjæring i Samfundet, som alt var tilstede.

Der trænges til en Ledelse fra oven, under hvilken alle Samfundsklasser kunne bringes til at deltage i det Arbeide, der sigter til at føre Folket en lykkelig Fremtid i Møde. Vi henvende os derfor til Tronen med det Ønske, at det maatte lykkes Deres Majestæts Visdom at tilveiebringe Betingelserne for en mere frugtbar Samvirken mellem Lovgivningsmagtens forskjellige Led og derved styrke Kærlighedsbaandet mellem Konge og Folk. ${ }^{8}$

Selv hvis man tager højde for den til genren hørende servile tone, er det klart, at appellen til kongen har taget form som et ønske om samvirke i overensstemmelse med ligevægtsteoriens ideal. Men netop i disse år forlod de fleste venstrefolk ligevægtsteorien. ${ }^{79} \mathrm{I}$ en adresse også til kongen tidligere samme år var nybruddet i Venstres taktik væsentligt klarere: «Opfyldelsen af det konstitutionelle Monarkis nødvendige Krav, at Regeringen er i Overensstemmelse med det af den almindelige Valgret udgaaede Thing ... er af afgjørende Betydning for Samfundets indre Udvikling.»" 80 Taktikken bestod ikke i at kræve en ny grundlovsændring, men simpelthen i at kræve en tilbagevenden til junigrundloven, idet man underforstod, at den i virkeligheden rummede forudsætninger for opfyldelsen af Venstres krav, eller som det hed i indledningen til Venstres første partiprogram fra $187^{2}$ : «Junigrundloven i dens fulde Omfang er Folkets moralske Ret.»

Der skete en stærk politisering af grundlovsspørgsmålet. Juraprofessor Henning Matzens forsvar for kongens fortsatte rolle som «Statsmagtens Tyngdepunkt», der ville have været et main-stream synspunkt på den grundlovgivende rigsforsamling, kunne nu entydigt identificeres som et stykke parti-ideologi. ${ }^{81}$ Matzen afskrives tilsvarende i historieskrivningen som usamtidig og uden forbindelse med den politiske virkelighed.

Dermed blev traditionen for omtolkninger af grundloven indledt, og denne tradition blev cementeret ved det såkaldte Systemskifte i 1901.

78. Rigsdagstidende. Forhandlinger paa Folkethinget. Ordentlige Samling $1873-74,2$ den Afdeling, sp. $23^{1} \mathrm{og}$ sp. 335. Vedtaget med 59 stemmer mod 27.

79. En undtagelse var Holstein-Ledreborg, der forblev en eksplicit tilhænger af det monarkiske princip. Rigsdagstidende. Forhandlinger paa Folkethinget. Ordentlige Samling 1873-74, 2den Afdeling, sp. 334-35. Se J. Wendel Hansen 2013.

8o. Ministerialtidende nr. 14, 1873:175.

81. Dagbladet 15. maj 1873. Cit. efter danmarkshistorien.dk, febr. 2013. 
Begivenheden selv bestod sådan set blot i, at Venstre overtog regeringsmagten, men den er siden blevet tillagt stadig mere principiel betydning på linje med det tilsvarende norske i 1884 .

Systemskiftet forstås som en sejr for den negative folketingsparlamentarisme, at ingen regering kan sidde med et folketingsflertal imod sig. Den tolkning, som Venstre havde lanceret under forfatningskampen, blev hegemonisk i en grad, så ligevægtsteorien blev fuldstændig glemt, også i statsforfatningsretten. Når der står «kongen» i grundloven, oversættes det pr. automatik til «regeringen».

Mens forholdet mellem regering og rigsdag med enkelte undtagelser har fungeret efter den negative parlamentarismes princip siden 1901, ophørte kongens indflydelse på regeringsdannelsen ikke. Monarkens fortsatte betydning som aktør på den politiske scene var accepteret, således at det i de første årtier af det 2o. århundrede stadig var vanskeligt at danne en regering, der gik imod kongens vilje, og det var en udfordring at træffe store regeringsbeslutninger, især når det handlede om landets forsvar, uden kongens samtykke. Disse to forhold var ikke særligt tydelige under Frederik VIII. Det skyldes ikke, at Frederik VIII tolkede grundloven væsentligt anderledes end sin far eller sin efterfølger, men blot at han politisk og personligt harmonerede med sine konseilspræsidenter, især J. C. Christensen. Uoverensstemmelserne var ikke så store, så kongens selvstændige rolle var simpelthen ikke nær så synlig set udefra. Sammme J. C. Christensen var det i øvrigt magtpåliggende, at Norge i 1905 bibeholdt den monarkiske forfatning, ikke ud fra en ideologisk forkærlighed for det monarkiske princip, men ud fra den mere generelle betragtning, at stabilitet var at foretrække ${ }^{82}$. Det synes at have været den generelle formel bag monarkiernes bemærkelsesværdige overlevelse i det 20. århundrede, at «if it works, don't fix it!».

Anderledes blev det under Christian X. Han bliver generelt i historieskrivningen bebrejdet, at han ikke havde forstået sin opgave som konstitutionel monark. Men som Knud Jespersen har vist, fortsatte han i vid udstrækning en praksis, der havde været accepteret eller tålt. Selv De Radikale accepterede de facto kongens indflydelse på politik. I den radikale historieskrivning har det været praksis at bebrejde kongen, at han ikke var radikal, og Christian $\mathrm{X}$ beskrives gerne som tungnem og i sine følelsers vold. Tage Kaarsted har undret sig over, hvordan kongen kunne mene, at han «havde både ret og pligt til personligt at gribe aktivt ind og træffe afgørelser også i sager af kontroversiel karakter», endskønt Kaar-

82. J. F. Møller, Dynastiet Glücksborg, Kbh. 2013: 134 . 


\section{MøLLER}

sted selv faktisk tydeligt viser, hvordan kongen af sine omgivelser blev opfattet som aktør i et politisk spil. ${ }^{83}$

Endnu i 194.o kunne det ikke lade sig gøre at danne en regering, som havde kongen imod sig. Men det betød ikke, at kongen kunne eller ville handle uafhængigt af det politiske flertal. Da en kreds af nationalkonservative med ingeniør Knud Højgaard i spidsen i november 1940 opfordrede kongen til at danne ?en upartisk regering? med kongens fætter prins Axel i spidsen, blev det afvist af kongen og statsministeren i forening. Hermed viste kongen, at han var fuldstændig loyal mod sin regering, og det vandt han bred anerkendelse for. I forbindelse med finanslovsdebatten i Folketinget fremhævede den konservative Ole Bjørn Kraft kongens positive rolle. Det blev en stående formel at omtale regering, rigsdag og konge som en sluttet enhed. I den samme debat bekræftede statsministeren denne opfattelse ved at tilslutte sig Krafts formulering:

Som det ærede Medlem Hr. Ole Bjørn Kraft har udtalt, er det Kongen, Regeringen og Folkerepræsentationen, der giver Treklangen i vor Forfatning. Disse tre Elementer maa virke sammen, og naar det sker, staar man paa Forfatningens Grund. ${ }^{8}$.

Denne udlægning af kongens rolle i statsstyret var ikke kun bestemt af situationen. Den var også udtryk for en genopvækning af elementer af den blandede forfatning. Parlamentarismen rykkede i baggrunden til fordel for en konsensusforståelse af forholdet mellem monarken, regeringen og Rigsdagen. Estrup ville ikke have været fremmed for den treklang, som både Kraft og Stauning talte om. Og Hal Koch, hvis begreb om politik blev til netop i perioden $1940^{-} 43$, gjorde denne konsensusforståelse til grundlag for sin stadig i dag meget udbredte forestilling om, hvad et ideelt demokrati er. Men det var ikke Estrups eller Hal Kochs opfattelse, der vandt, men derimod den, at Rigsdagen - fra 1953 med kun ét kammer - er en arena for den legitime politiske kamp, der udkæmpes med kvantitetens barbari, som kritikerne siger, det vil sige ved hjælp af afstemninger, og at der mellem statens elementer, rigsdag, regering og statsoverhoved eksisterer en fast, sædvanebetinget, hierarkisk struktur, hvis modus operandi som vist ligger langt fra grundlovens faktiske ordlyd og oprindelige intention.

83. T. Kaarsted, Påskekrisen 192o, Kbh. 1968: 51.

84. Rigsdagstidende, Folketinget, 1940-4,1, sp. 561. O. B. Krafts oprindelige indlæg, som Stauning citerer, se sp. 477 . 